\title{
Androgen Receptor-Mediated Regulation of Intracellular Calcium in Human Airway Smooth Muscle Cells
}

\author{
Rama Satyanarayana Raju Kalidhindi ${ }^{a}$ Rathnavali Katragadda ${ }^{a}$ \\ Kerri L. Beauchamp ${ }^{\mathrm{a}}$ Christina M. Pabelick ${ }^{\mathrm{b}, \mathrm{c}} \quad$ Y.S. Prakash ${ }^{\mathrm{b}, \mathrm{c}}$ \\ Venkatachalem Sathish ${ }^{a}$
}

aDepartment of Pharmaceutical Sciences, North Dakota State University, Fargo, ND, USA, bDepartment of Anesthesiology and Perioperative Medicine, Mayo Clinic, Rochester, MN, USA, 'Department of Physiology and Biomedical Engineering, Mayo Clinic, Rochester, MN, USA

\section{Key Words}

Sex Difference $\bullet$ Sex Steroid $\bullet$ Testosterone $\cdot$ Airway $•$ Asthma $\bullet$ Contractility

\begin{abstract}
Background/Aims: With the prevalence of asthma being greater in women, detrimental effects of female sex steroids have been explored, but potential protective effects of androgens are not established. Airway smooth muscle (ASM) is a key cell type in contractility and remodelling of asthma. There are no data on expression and functionality of androgen receptor (AR) in human ASM cells. Methods: We used primary human ASM cells from non-asthmatics vs. asthmatics to determine AR expression at baseline and with inflammation measured using Western blotting/qRT-PCR, and the role of AR in regulating intracellular $\mathrm{Ca}^{2+}\left(\left[\mathrm{Ca}^{2+}\right]_{\mathrm{i}}\right)$ measured using Fluo-3 loaded real time $\left[\mathrm{Ca}^{2+}\right]_{\mathrm{i}}$ imaging. Results: We found that compared to females, baseline AR is greater in male ASM and increases with inflammation/asthma. Androgens, via AR, blunted TNF $\alpha$ or IL-13-induced enhancement of ASM $\left[\mathrm{Ca}^{2+}\right]_{i}$ in both males and females, with retained efficacy in asthmatics. AR effects involve reduced $\mathrm{Ca}^{2+}$ influx via L-type channels and store-operated $\mathrm{Ca}^{2+}$ entry, the latter by downregulating STIM1 and Orai 1 and increasing TMEM66. Conclusion: Our data show AR expression is increased in female ASM with asthma, but has retained functionality that could be used to reduce $\left[\mathrm{Ca}^{2+}\right]_{i}$ towards alleviating airway hyperresponsiveness.

\section{Introduction}

Bronchial asthma is a leading cause of morbidity across the age spectrum, and involves increased airway inflammation, epithelial mucus secretion, airway hyperreactivity involving enhanced airway smooth muscle (ASM) contractility, and chronic airway remodelling, the 


\section{Cellular Physiology Cell Physiol Biochem 2019;53:215-228

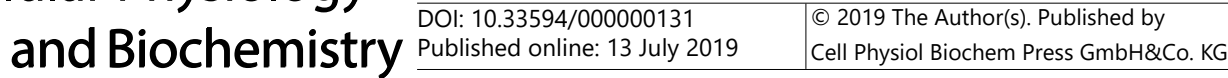 \\ Kalidhindi et al.: Androgen Receptor in Airway Smooth Muscle}

latter a result of increased cell proliferation and fibrosis $[1,2]$. Asthma in adults shows a sex difference where for example, in $2014, \sim 60 \%$ of the 3,651 deaths attributed to asthma occurred in women (American Lung Association) [3]. Amongst the general adult population, asthma prevalence is higher in women than men with distinctive changes in the prevalence and severity of asthma with age $[4,5]$. Asthma increases steadily in both sexes from birth onwards to the early teenage years, but is significantly higher in males. From teenage years through midlife, prevalence decreases dramatically in males, but increases in females. With subsequent aging, prevalence increases in males and decreases in females, converging in late adulthood $[4,6]$. These clinical data highlight the potential modulatory role of sex hormones on the prevalence and severity of asthma.

The effects of the sex steroids estrogen $\left(\mathrm{E}_{2}\right)$, progesterone $(\mathrm{P})$ and testosterone (TES) in the context of asthma have been explored to varying extents in different elements of the bronchial airways (reviewed in [5, 7, 8]). One obvious point from studies done in different species (including humans), cell types (epithelium, ASM, fibroblasts, immune cells) and experimental interventions is that sex steroid effects in the airways are cell- and contextspecific [5]. Thus, understanding sex steroid biology in the context of asthma and sex differences necessitates studies in specific cell types.

ASM is a major cell type in asthma given its importance to airway contraction and relaxation [5, 8-11] as well as airway remodeling [12-15]. Here, previous studies including our own have demonstrated an alleviating effect of female sex steroids particularly estrogens in regulation of ASM intracellular $\mathrm{Ca}^{2+}\left(\left[\mathrm{Ca}^{2+}\right]_{\mathrm{i}}\right)[16]$, proliferation and extracellular matrix (ECM) production [14]. While the focus on estrogens is appropriate, the effects on $\left[\mathrm{Ca}^{2+}\right]_{\mathrm{i}}$ or remodeling run counter to the greater incidence of asthma in women, raising the question of whether it should be important to also explore the effect of male sex steroids to better understand sex differences.

Androgens are known to regulate intracellular calcium $\left[\mathrm{Ca}^{2+}\right]_{\mathrm{i}}$ levels and contractility of various smooth muscle types [16-22]. Androgens such as testosterone (TES) and DiHydro Testosterone (DHT- an active metabolite of TES) have been found to relax smooth muscle and non-genomically decrease $\mathrm{Ca}^{2+}$ influx through L-type calcium channels (LTCC), large-conductance $\mathrm{Ca}^{2+}$-activated potassium $\left(\mathrm{BK}_{\mathrm{Ca}}\right)$ channels, store operated $\mathrm{Ca}^{2+}$ channels (SOCC) and myosin light chain (MLC) phosphorylation [17, 19, 23-27]. The relaxant effects of androgen agonists on tracheal smooth muscle cells in animal models of asthma have been previously explored, with biological actions of TES and DHT shown to be mediated by the high-affinity androgen receptor (AR), a member of the nuclear receptor superfamily, which in response to hormone regulates gene expression in target tissues [28-31], including AR expression itself [28]. Studies in airway tissues from different animal species (especially guinea pig) found that AR activation modulates LTCCs and SOCC [25] as well as modulation of IP3 receptors [32], with effects being epithelium and potassium channel independent [33], and similar effects of Dehydroepiandrosterone (DHEA) in asthmatic guinea pig models [31]. In contrast, epithelium-dependent relaxation in rabbit trachea by TES has also been reported [26]. However, all of these studies, including the expression of AR and non-genomic effects of AR activation have been performed in animal models or cells, with no studies on AR expression in human airways or their mechanisms of action.

In this novel study, we explore the expression of AR in primary human ASM cells derived from non-asthmatic vs. asthmatic patients of both genders, and the modulatory effect of inflammatory cytokines. Furthermore, the genomic effect of AR activation on $\left[\mathrm{Ca}^{2+}\right]$ regulation is explored. We hypothesize that the AR expression is increased during asthma/ inflammation and AR activation downregulates $\left[\mathrm{Ca}^{2+}\right]_{\mathrm{i}}$ in a genomic fashion, thus helping to blunt airway hyperresponsiveness (AHR). 


\section{Cellular Physiology Cell Physiol Biochem 2019;53:215-228 \begin{tabular}{l|l|l} 
DOI: 10.33594/000000131 & ( 2019 The Author(s). Published by
\end{tabular} and BIOChemistry Published online: 13 July $2019 \quad$ Cell Physiol Biochem Press GmbH\&Co. KG \\ Kalidhindi et al:: Androgen Receptor in Airway Smooth Muscle}

\section{Materials and Methods}

\section{Chemicals, drugs/inhibitors, antibodies}

Cell culture reagents and other cell culture supplies including fetal bovine serum (FBS) and Dulbecco's Modified Eagle's Medium F/12 (DMEM/F12) were purchased from Invitrogen (Carlsbad, CA). Proinflammatory cytokines tumor necrosis factor alpha (TNF $\alpha$ ) and interleukin-13 (IL-13) were purchased from Santa Cruz Biotechnology, Inc (Dallas, TX). Pharmacological modulators for AR, Testosterone (TES) and Flutamide were obtained from Tocris (Minneapolis, MN). CPA was procured from ChemCruz. Antibodies; Androgen Receptor Santa Cruz Biotechnology, Inc (Dallas, TX) and $\beta$-actin Applied Biological Materials, Inc (Richmond, BC). All other chemicals and supplies were from Sigma (St. Louis, MO) unless otherwise specified.

\section{Human ASM cells}

The technique for isolating human ASM cells has been previously described [18, 34, 35]. Third to sixth generation human bronchi were obtained from lung specimen's incidental to patient thoracic surgery at Mayo Clinic for focal, non-infectious causes (typically lobectomies for focal cancers). Normal lung areas were identified with the help of a pathologist (protocol approved by Mayo Clinic Institutional Review Board). Samples were denuded of epithelium and ASM tissue enzymatically dissociated to generate cells for experiments $\left(<5^{\text {th }}\right.$ passage). Cells were maintained under standard conditions of $37^{\circ} \mathrm{C}\left(5 \% \mathrm{CO}_{2}, 95 \%\right.$ air $)$. Cells were serum starved for $24 \mathrm{~h}$ prior to experimentation.

\section{Cell Treatments}

Human ASM cells in T-75 flasks were trypsinized and mixed in 10\% FBS (Charcoal Stripped) Growth medium (DMEM/F12 with 1\% AbAm), counted and seeded 10, 000 cells/well into 8-well chamber slides. Cells were incubated overnight followed by serum deprivation (DMEM/F12 without FBS) for $24 \mathrm{~h}$. ASM cells were treated with AR agonists Testosterone (TES, $10 \mathrm{nM}$ ) or 5 -alpha-DiHydro Testosterone ( $5 \alpha \mathrm{DHT} /$ DHT, $10 \mathrm{nM}$ ) with or without flutamide (AR antagonist) in serum free media. After $2 \mathrm{~h}$ of pre-incubation with respective treatment groups, cells were then exposed to TNF $\alpha\left(20 \mathrm{ngml}^{-1}\right)$ or IL-13 $\left(50 \mathrm{ngml}^{-1}\right)$ for $24 \mathrm{~h}$. Serum free media alone served as vehicle. Similarly, ASM cells were grown on $100 \mathrm{~mm}$ petri plates and treated as above to collect lysates for protein or mRNA for western and qRT-PCR analysis respectively.

\section{qRT-PCR Analysis}

Cells were washed with RNA-grade DPBS, trypsinized and centrifuged. Total RNA was extracted using Quick-RNA ${ }^{\text {TM }}$ MiniPrep kit (Zymo Research, Irvine, CA) following manufacturer's protocol. cDNA was synthesized using OneScript cDNA Synthesis Kit using 500-600ng of quantified RNA (Take3 ${ }^{\text {TM }}$ Micro volume plate, Synergy HTX, Biotek, USA) for each sample (Applied Biological Materials Inc, Richmond, BC, Canada). LightCycler 480 SYBR Green I Master PCR kit (Cat\# 0470751601) protocol was followed using QuantStudio 3 RT-PCR system as per the manufacturer's instructions. The following primers were used for RT-PCR analysis: AR (forward 5'-GCC TTG CTC TCT AGC CTC AA-3', reverse 5'-GGT CGT CCA CGT GTA AGT TG-3') and s16 (forward 5'-CAA TGG TCT CAT CAA GGT GAA CGG-3', reverse 5'-CTG GAT AGC ATA AAT CTG GGC- $\left.3^{\prime}\right)$. The fold changes in mRNA expression were calculated by normalization of cycle threshold [C( $\left.\left.t\right)\right]$ value of target genes to reference gene s16 using the $\Delta \Delta \mathrm{Ct}$ method $[14,15,36]$.

\section{Western analysis}

Previously described techniques were used [14,37]. Briefly, cells were washed, sonicated in lysis buffer (Cell Signaling Technologies, Beverly, MA, USA) containing protease and phosphatase inhibitors, and resultant supernatants were assayed for total protein content using the DC Protein Assay kit (BioRad, Hercules, CA, USA). $30 \mu$ g equivalent protein from each lysate were loaded on 4-15\% SDS-page and transferred onto 0.22 $\mu \mathrm{m}$ PVDF membranes. Non-specific binding was blocked using $5.0 \%$ bovine serum albumin (BSA) and the membranes were probed overnight at $4^{\circ} \mathrm{C}$ with specific primary antibodies of interest (Androgen receptor, STIM1, Orai-1 and TMEM66 with $\beta$-actin as a loading control). Blots were then incubated with LiCOR nearred conjugated or HRP conjugated secondary antibodies. Membranes were scanned using LiCOR Odyssey CLX or developed on radiography films and densitometry analysis was performed using Image Studio version 5.2 software or Image J (NIH). 


\section{Cellular Physiology Cell Physiol Biochem 2019;53:215-228 \\ \begin{tabular}{c|c|c|c|c|}
\hline Dol: 10.33594/000000131 & 2019 The Author(s). Published by \\
\hline
\end{tabular} \\ \begin{tabular}{ll} 
Published online: 13 July 2019 & Cell Physiol Biochem Press GmbH\&Co. KG \\
\hline
\end{tabular} \\ Kalidhindi et al:: Androgen Receptor in Airway Smooth Muscle}

\section{Real-time Intracellular Calcium $\left[\mathrm{Ca}^{2+}\right]_{i}$ Imaging}

After 24 hours of incubation with the respective treatments, drug solutions (media) were aspirated and human ASM cells were washed with freshly prepared HBSS (1X) buffer solution. Further, they were incubated with $4 \mu \mathrm{M}$ Fluo-3 dye (prepared in HBSS solution) for $1 \mathrm{~h}$ at room temperature. Following an hour, the dye was aspirated, and cells were washed twice with HBSS buffer solution. The ASM cells were imaged at a 20X oil-magnification on GFP fluorescence (excitation 475-495 nm, and emission 520-560 nm) in the Biotek Lionheart FX automated live cell imaging system [16, 34, 38-40].

\section{AR siRNA studies}

Human ASM cells were cultured in 8-well plates or $100 \mathrm{~mm}$ plates to approximately $50 \%$ confluence. Transfection was achieved using $20 \mathrm{nM}$ AR siRNA (Cat\# SO-2685308G) and Lipofectamine 3000 transfection reagent (Invitrogen) in DMEM/F-12 and 5\% FBS lacking antibiotics. Fresh growth medium was added after $6 \mathrm{~h}$ and cells were analyzed after $48 \mathrm{~h}$. Negative Control siRNA (Cat\# AM4611) was procured from Ambion. Efficacy and specificity of siRNA knockdown was verified using Western analysis. The effect of AR siRNA on $\left[\mathrm{Ca}^{2+}\right]_{\mathrm{i}}$ in the presence and absence of TNF $\alpha$, IL-13 and Testosterone were analyzed as mentioned above.

\section{Store Operated Calcium Entry (SOCE)}

For SOCE imaging, cells were washed with HBSS (with $2.5 \mathrm{mM} \mathrm{Ca}^{2+}$ ) and then loaded with $4 \mu \mathrm{M}$ Fluo-3 AM dye for $1 \mathrm{~h}$ at room temperature. The cells were then washed three times with $1 \mathrm{X}$ HBSS ("0" calcium) and proceeded with imaging in an Olympus FV-300 imaging station with shutter control system and CCD camera using a FITC filter. Solutions were added to the wells using a peristaltic pump system with a fixed flow rate. The overflowing solution was aspirated using a vacuum pump attached to the system. Initially HBSS without calcium was passed and for $2 \mathrm{~min}$, followed by HBSS (without calcium) with $10 \mu \mathrm{M}$ KCL for $4 \mathrm{~min}$ and HBSS (without calcium) with $10 \mu \mathrm{M}$ KCL and $1 \mu \mathrm{M}$ Nifedipine for $4 \mathrm{~min}$. Images were captured every 10 seconds using Cell Sens software. The cells were then subjected to HBSS ("0" calcium) with $10 \mu \mathrm{M} \mathrm{KCL,} 1 \mu \mathrm{M}$ Nifedipine and $10 \mu \mathrm{M}$ CPA for 4 minutes, followed by introducing $\mathrm{Ca}^{2+}$ in the same solution for 2 minutes. During this phase, images were captured every 1 second. Region of interest's (ROI) were selected randomly from 5-10 cells and change in fluorescence intensity was recorded using Cell Sense software (Olympus Inc., USA) $[38,40]$.

\section{Statistical analysis}

Experiments were performed in human ASM cells from 3-5 patients (non-asthmatic males, nonasthmatic females, asthmatic males and asthmatic females). " $n$ " values represent patient numbers for individual experiments. All the experiments were repeated at least two times for each patient sample. Data expressed as mean \pm SEM. Statistical analysis was performed using individual one-way ANOVA or two-way ANOVA with Bonferroni post-hoc test where applicable. Statistical significance was tested at minimum of $\mathrm{p}<0.05$ level.

\section{Results}

\section{AR expression in human ASM cells}

Baseline mRNA expression of AR was significantly higher $(\mathrm{p}<0.05)$ in male non-asthmatic human ASM cells compared to female non-asthmatic ASM cells. Western analysis of ASM cell lysates also indicated significantly higher $(\mathrm{p}<0.01)$ AR expression in male non-asthmatics compared to female non-asthmatics. In asthmatic human ASM cells, AR mRNA and protein expression were significantly greater in both males $(\mathrm{p}<0.05$ for mRNA and $p<0.01$ for protein) and females ( $\mathrm{p}<0.05$ for mRNA and $\mathrm{p}<0.01$ for protein) compared to non-asthmatic human ASM cells (Fig. 1A and 1B). Notably, AR expression was markedly greater in female asthmatic ASM cells compared to non-asthmatics and the increase was comparable to that in males (Fig. 1A, B). 
Fig. 1. Androgen receptor (AR) expression in nonasthmatic (NA) and asthmatic human ASM cells (males and females) using qRT-PCR and Western analysis. A) mRNA expression of AR using qRTPCR in non-asthmatic and asthmatic human ASM cells of both genders. S16 was used as internal control for normalization. B) Protein expression of AR using Western analysis in non-asthmatic and asthmatic human ASM cells of both genders. $\beta$-actin was used as loading control for normalization. AR-expression is physiologically low in females compared to males and is increased during asthma in both males and females. ${ }^{\#}<0.05 ;{ }^{\# \#}<<0.01$ vs. non-asthmatic female or male, ${ }^{*} \mathrm{p}<0.05,{ }^{* *} \mathrm{p}<0.01$ vs. non-asthmatic females. Data expressed as mean \pm SEM. $n=5$ patients each.

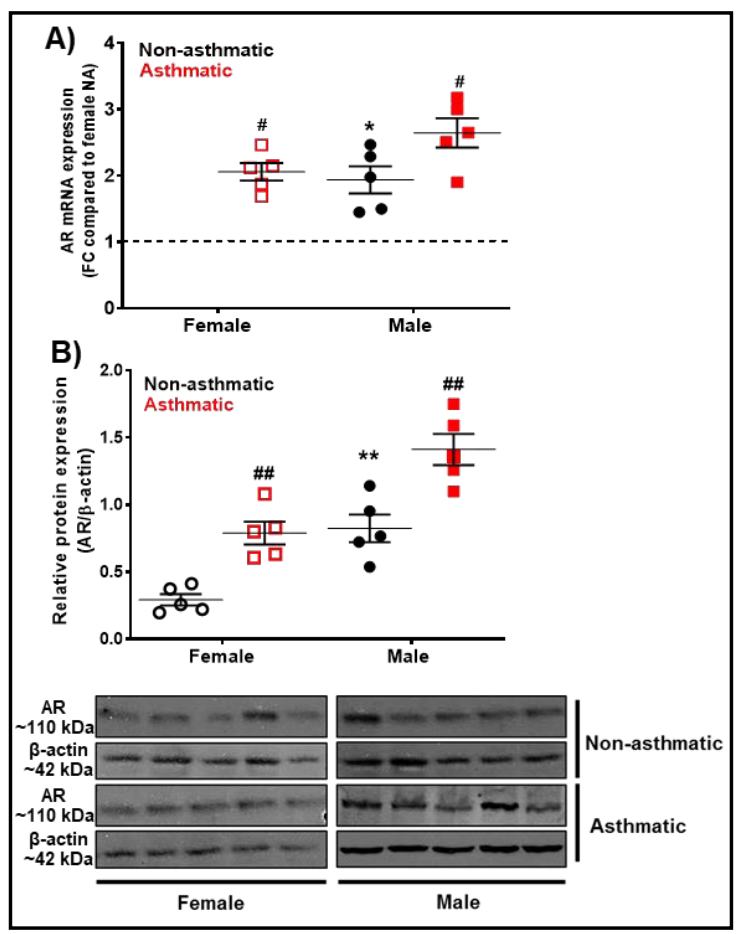

Fig. 2. Androgen receptor (AR) expression with pro-inflammatory cytokine exposure (TNF $\alpha$ and IL-13) in non-asthmatic and asthmatic human ASM cells (males and females). A) AR expression in non-asthmatic human ASM cells (both male and female) using qRTPCR analysis; B) AR expression in asthmatic human ASM cells (both male and female) using qRT-PCR analysis. S16 was used as internal control for normalization. C) AR expression in non-asthmatic human ASM cells (both male and female) using western analysis and D) AR expression in asthmatic human ASM cells (both male and female) using western analysis.

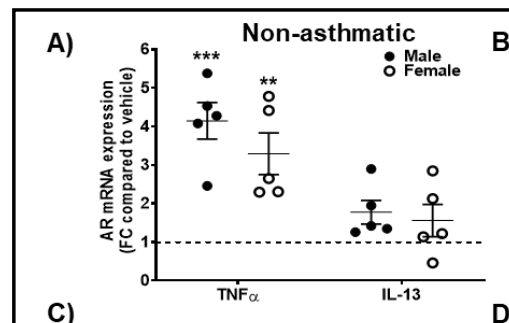

C)

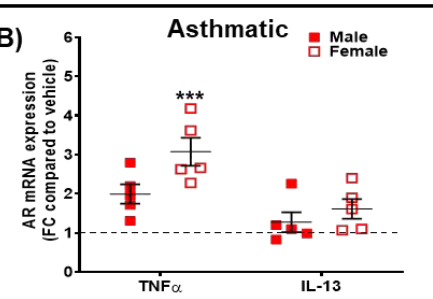

D)

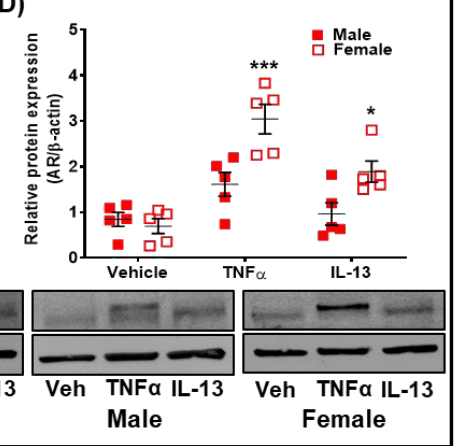

$\beta$-actin was used as internal control for normalization. AR expression is significantly increased during inflammation, especially in female ASM with pronounced changes observed in TNF $\alpha$ exposed asthmatic female ASM. ${ }^{*} \mathrm{p}<0.05 ;{ }^{* *} \mathrm{p}<0.01$ and ${ }^{* * *} \mathrm{p}<0.001$ vs. vehicle. Data expressed as mean \pm SEM. $\mathrm{n}=5$ patients each.

\section{Effect of inflammation on AR expression in human ASM cells}

In non-asthmatic human ASM cells of both males $(\mathrm{p}<0.001)$ and females $(\mathrm{p}<0.01), A R$ mRNA expression was significantly increased in the presence of TNF $\alpha\left(20 \mathrm{ngml}^{-1}\right)$ compared to vehicle, while no significant increase was observed in cells exposed to IL-13 (50 ngml $\left.{ }^{-1}\right)$. In addition, AR mRNA expression was significantly increased ( $\mathrm{p}<0.001)$ in asthmatic females in the presence of $\mathrm{TNF} \alpha$, while no significant changes were observed in male asthmatics exposed to TNF $\alpha$ (Fig. 2A, B). IL-13 exposed asthmatic ASM cells did not show any significant 


\section{Cellular Physiology Cell Physiol Biochem 2019;53:215-228 \\ \begin{tabular}{ll|l} 
and Biochemistry $10.33594 / 000000131$ & $\begin{array}{l}\text { Dublished online: } 13 \text { July } 2019 \\
\text { Pell Physiol Biochem Press GmbH\&Co. KG }\end{array}$ \\
\hline
\end{tabular} \\ Kalidhindi et al.: Androgen Receptor in Airway Smooth Muscle}

changes in AR mRNA expression. TNF $\alpha$-induced increase in AR mRNA expression was more pronounced in female asthmatic human ASM $(p<0.001)$ compared to males; whereas, in nonasthmatic human ASM cells AR mRNA expression was more in males $(\mathrm{p}<0.001)$ compared to females ( $p<0.01$, Fig. $2 A$ and $2 B)$. Western analysis revealed a significant increase in AR expression in non-asthmatic males and females $(\mathrm{p}<0.001)$ exposed to TNF $\alpha$. Interestingly, IL-13 exposed cells also showed a significant increase in AR protein in male non-asthmatics $(\mathrm{p}<0.001)$ and female non-asthmatics $(\mathrm{p}<0.01)$ compared to vehicle. However, in asthmatic ASM cells, only females showed significant increase in AR expression in the presence of TNF $\alpha$ $(\mathrm{p}<0.001)$ or IL-13 $(\mathrm{p}<0.05)$ compared to vehicle (Fig. 2C and 2D).

\section{Effect of AR activation on $\left[\mathrm{Ca}^{2+}\right]_{i}$ regulation in human ASM cells}

Imaging studies using Fluo-3 loaded human ASM cells showed a significant enhancement of histamine-elicited $\left[\mathrm{Ca}^{2+}\right]_{\mathrm{i}}$ response following exposure to TNF $\alpha$ compared to vehicle in both non-asthmatics ( $\mathrm{p}<0.001$ for males and females) and asthmatics $(\mathrm{p}<0.001$ for males and females). TNF $\alpha$ enhancement of $\left[\mathrm{Ca}^{2+}\right]_{\mathrm{i}}$ tended higher in asthmatics compared to nonasthmatics. $24 \mathrm{~h}$ exposure of TES $(10 \mathrm{nM})$ did not show any significant effects on $\left[\mathrm{Ca}^{2+}\right]_{\mathrm{i}}$ responses to histamine in either non-asthmatic or asthmatic ASM cells. However, both nonasthmatic and asthmatic ASM cells treated with TES followed by TNF $\alpha$ exposure showed a significant decrease $(p<0.001$ for males and $p<0.01$ for females in non-asthmatics and $p<0.01$ for males and $\mathrm{p}<0.001$ for females in asthmatics) compared to TNF $\alpha$ alone. Here, the effects of TES were abrogated by flutamide (Fig. 3A and 3B), highlighting the role of AR activation. In addition, cells treated with DHT $(10 \mathrm{nM})$ followed by TNF $\alpha$ exposure showed significant decrease in $\left[\mathrm{Ca}^{2+}\right]_{\mathrm{i}}$ response in both males and females for non-asthmatics $(\mathrm{p}<0.001$ in males and $\mathrm{p}<0.01$ in females) and asthmatics ( $\mathrm{p}<0.001$ in males and females) compared to TNF $\alpha$ alone (Fig. 3C and 3D). Here, the effect of DHT on reducing $\left[\mathrm{Ca}^{2+}\right]_{\mathrm{i}}$ response induced by TNF $\alpha$ was more prominent in asthmatics compared to non-asthmatics. DHT effect was inhibited in the presence of flutamide. Human ASM cells treated with DHT alone did not show any notable changes in $\left[\mathrm{Ca}^{2+}\right]_{\mathrm{i}}$ compared to vehicle.

Fig. 3. Effect of Testosterone (TES) and $5 \alpha$-Dihydrotestosterone (DHT) on regulating $\left[\mathrm{Ca}^{2+}\right]$ during TNF $\alpha$ exposure in human ASM cells. Effect of TES on regulating $\left[\mathrm{Ca}^{2+}\right]$ response to histamine in the presence/absence of TNF $\alpha$ in A) Non-asthmatic human ASM cells (male and female) and B) Asthmatic human ASM cells (male and female). Effect of DHT on regulating $\left[\mathrm{Ca}^{2+}\right]_{i}$ response to histamine in the presence/absence of $\mathrm{TNF} \alpha$ in C) Non-asthmatic human ASM cells (male and female) and D) Asthmatic human ASM cells (male and female). $\mathrm{TNF} \alpha$ significantly increased $\left[\mathrm{Ca}^{2+}\right]$ response to histamine in both i non-asthmatic and asthmatic ASM cells (male and female) compared to vehicle, while TES and/or DHT treatment significantly downregulated the TNF $\alpha$ induced increase in $\left[\mathrm{Ca}^{2+}\right]_{\text {levels. }}{ }^{\# \#} \mathrm{p}<0.001$ vs. vehicle, ${ }^{* *} \mathrm{p}<0.01$ and ${ }^{* * *} \mathrm{p}<0.001$ vs. TNF $\alpha$. Data expressed as mean $\pm \mathrm{SEM}$. $\mathrm{n}=3$ patients each.

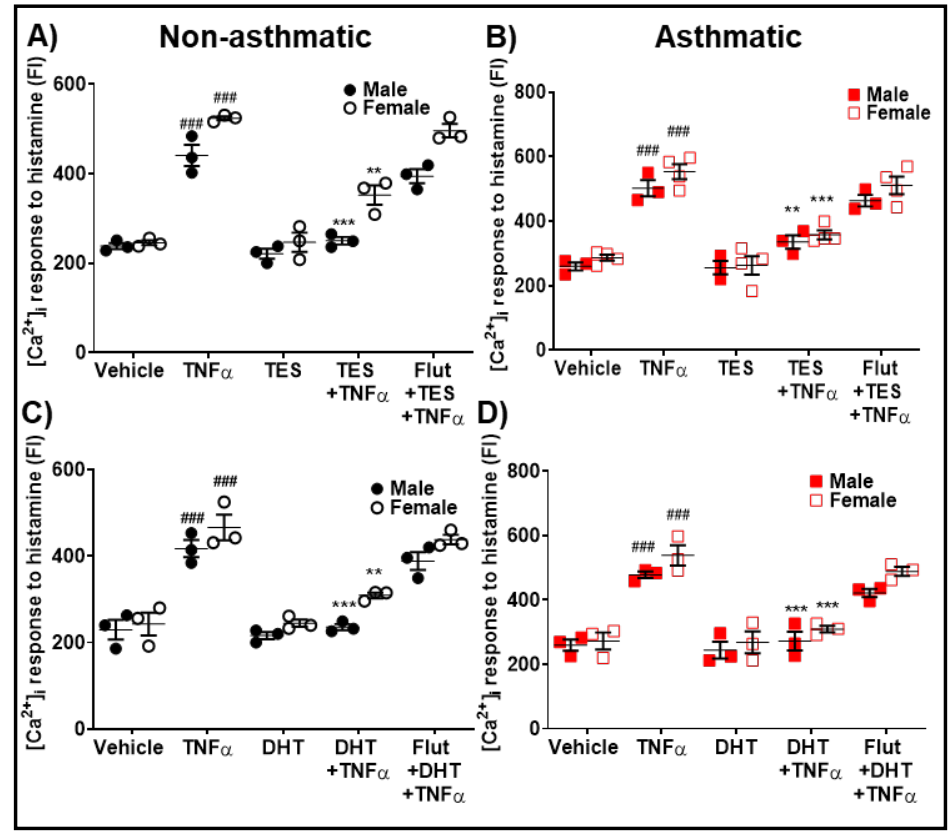


Fig. 4. Effect of TES and DHT on regulating $\left[\mathrm{Ca}^{2+}\right]$ during $\mathrm{IL}-13$ exposure in human ASM cells. Effect of TES on regulating $\left[\mathrm{Ca}^{2+}\right]$ response to histamine in the presence/absence of $\mathrm{IL}-13$ in A) Non-asthmatic human ASM cells (male and female) and B) Asthmatic human ASM cells (male and female). Effect of DHT on regulating $\left[\mathrm{Ca}^{2+}\right]$ response to histamine in the presence/absence of IL-13 in C) Non-asthmatic human ASM cells (male and female) and D) Asthmatic human ASM cells (male and female). IL13 significantly increased $\left[\mathrm{Ca}^{2+}\right]$

in both non-asthmatic and asthmatic human ASM cells (male and female) compared to vehicle.

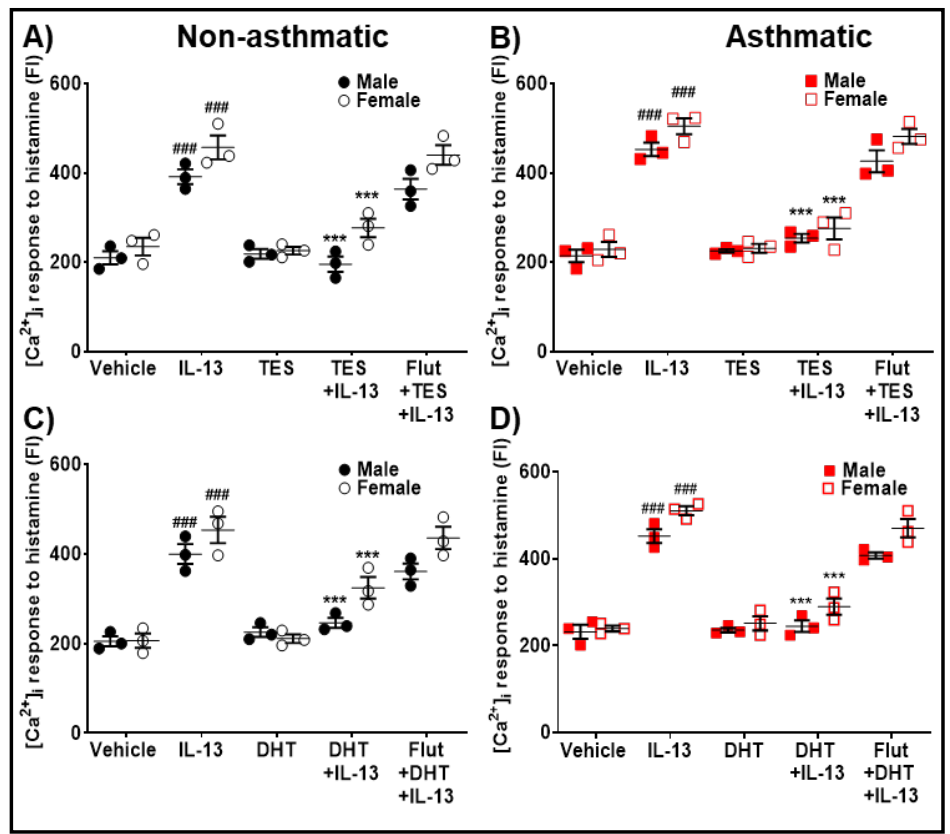
TES and/or DHT treatment significantly downregulated the IL-13 induced increase in $\left[\mathrm{Ca}^{2+}\right]$ response to histamine. ${ }^{\# \#} \mathrm{p}<0.001$ vs. vehicle and ${ }^{* * *} p<0.001$ vs. TNF $\alpha$. Data expressed as mean \pm SEM. $n=3$ patients each.

Exposure to IL-13 resulted in a significant increase ( $p<0.001$ in males and females) in $\left[\mathrm{Ca}^{2+}\right]_{\mathrm{i}}$ responses to histamine for both non-asthmatics and asthmatic human ASM cells. Treatment with TES blunted the effects of IL-13 in non-asthmatic and asthmatic ASM ( $p<0.001$ both male and female, Fig. 4A and 4B). In the presence of IL-13, DHT treated ASM cells showed significant reduction in $\left[\mathrm{Ca}^{2+}\right]_{\mathrm{i}}$ response $(\mathrm{p}<0.001$, Fig. $4 \mathrm{C}$ and $4 \mathrm{D})$ compared to IL-13 alone. The inhibitory effects of TES and DHT on $\left[\mathrm{Ca}^{2+}\right]_{\mathrm{i}}$ in IL-13 exposed cells was not observed in the presence of flutamide.

\section{Mechanisms of AR-mediated effects on $\left[\mathrm{Ca}^{2+}\right]_{i}$ regulation}

Removal of extracellular $\mathrm{Ca}^{2+}$ still resulted in histamine-induced $\left[\mathrm{Ca}^{2+}\right]_{\mathrm{i}}$ responses that were enhanced by TNF $\alpha$ in both non-asthmatic $(\mathrm{p}<0.001)$ and asthmatic $(\mathrm{p}<0.001)$ ASM cells. TNF $\alpha$ induced increase in $\left[\mathrm{Ca}^{2+}\right]_{\mathrm{i}}$ was significantly downregulated by TES in non-asthmatic $(\mathrm{p}<0.001)$ and asthmatic $(\mathrm{p}<0.001)$ ASM cells. Similarly, even in zero extracellular $\mathrm{Ca}^{2+}, \mathrm{IL}-13$ enhanced $\left[\mathrm{Ca}^{2+}\right]_{\mathrm{i}}$ responses to histamine in non-asthmatic $(\mathrm{p}<0.001)$ and asthmatic $(\mathrm{p}<0.001)$ ASM cells: effects significantly inhibited by TES in non-asthmatic $(\mathrm{p}<0.05$ for males and $\mathrm{p}<0.01$ for females) and asthmatic ( $\mathrm{p}<0.05$ for males and females) cells. TES effects were not observed in the presence of flutamide (Fig. 5A and 5B).

To confirm the role of ARs, we used siRNA to knockdown AR expression in ASM cells. siRNA knockdown efficiency was confirmed using Western analysis $(\sim 70 \%$ reduction; Fig. $6 \mathrm{~A}, \mathrm{~B})$. AR siRNA transfected cells were exposed to TES $(10 \mathrm{nM})$ for $2 \mathrm{~h}$ and further treated with TNF $\alpha$ or IL-13 for $24 \mathrm{~h}$ followed by real-time $\left[\mathrm{Ca}^{2+}\right]_{\mathrm{i}}$ imaging. AR siRNA transfected ASM cells continued to show a significant increase in $\left[\mathrm{Ca}^{2+}\right]_{i}$ response to histamine following exposure to TNF $\alpha(\mathrm{p}<0.001)$ and IL-13 $(\mathrm{p}<0.05)$ compared to negative siRNA; however, TES did not have any significant effects following with AR siRNA (Fig. 6B).

Non-asthmatic ASM cells from males exposed to nifedipine (15 min) showed significant $(\mathrm{p}<0.05)$ decrease in $\left[\mathrm{Ca}^{2+}\right]_{\mathrm{i}}$ responses to histamine compared to vehicle (no nifedipine). Nifedipine did not eliminate TNF $\alpha$ enhancement of $\left[\mathrm{Ca}^{2+}\right]_{i}$, which was significantly reduced $(p<0.01)$ in cells treated with TES. Similar findings were observed in the case of IL-13 exposed human ASM cells, where a significant increase $(\mathrm{p}<0.05)$ in $\left[\mathrm{Ca}^{2+}\right]_{\mathrm{i}}$ response was observed, which was significantly reversed $(\mathrm{p}<0.01)$ in TES treated cells (Fig. 6C). TES treated cells 
in the presence of Nifedipine did not show any significant changes in $\left[\mathrm{Ca}^{2+}\right]_{\mathrm{i}}$ response to histamine compared to Nifedipine alone treated cells indicating the effect is partly through LTCC.

Fig. 5. Effect of TES on regulating $\left[\mathrm{Ca}^{2+}\right]$ in human ASM cells in zero extracellular calcium environment during TNF $\alpha$ and IL-13 exposure. A) Effect of TES on regulating $\left[\mathrm{Ca}^{2+}\right]$ in non-asthmatic human ASM cells (male and female) and B) Effect of TES on regulating $\left[\mathrm{Ca}^{2+}\right]$ in asthmatic human ASM cells (male and female). TNF $\alpha$ and IL-13 significantly increased the $\left[\mathrm{Ca}^{2+}\right]$ response to histamine in non-asthmatic and asthmatic human ASM cells compared to vehicle. This increase in $\left[\mathrm{Ca}^{2+}\right]$ was significantly inhibited in ASM cells treated with TES, while ASM cells exposed to Flutamide before TES administration did not show any significant downregulation of TNF $\alpha / \mathrm{IL}-$ 13 induced increase in $\left[\mathrm{Ca}^{2+}\right]$. ${ }^{\# \#} \mathrm{p}<0.001$ vs. vehicle, ${ }^{*} \mathrm{p}<0.05,{ }^{* *} \mathrm{p}<0.01$ and ${ }^{* * *} \mathrm{p}<0.001$ vs. cytokines. Data expressed as mean \pm SEM. $n=3$ patients each.

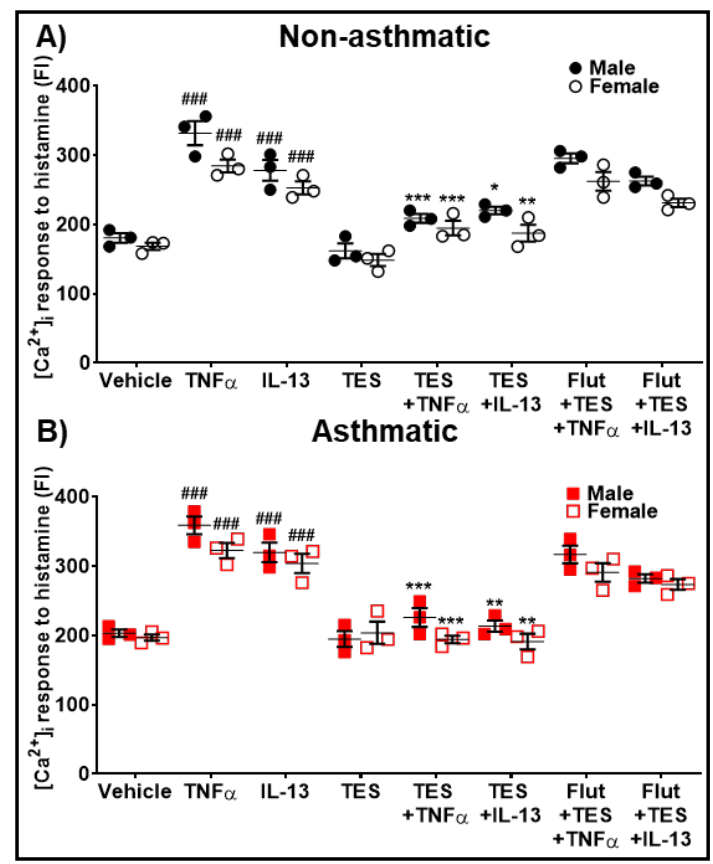

Fig. 6. Effect of TES on regulating $\left[\mathrm{Ca}^{2+}\right]$ during pro-inflammatory cytokine exposure (TNF $\alpha$ and IL-13) in AR siRNA knockdown ASM cells and ASM cells exposed to Nifedipine (L-type calcium channel inhibitor). A) Confirmation of AR knockdown using siRNA by western analysis. B) Representative blot showing downregulated AR with siRNA knockdown. C) Effect of TES on regulating $\left[\mathrm{Ca}^{2+}\right]$ in AR siRNA knockdown non-asthmatic human ASM cells in response to histamine. D) Effect of TES on regulating $\left[\mathrm{Ca}^{2+}\right]$ response to histamine in the presence of Nifedipine in non-asthmatic human ASM cells.

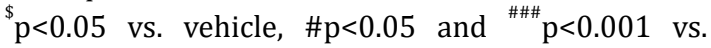
neg. siRNA/vehicle (+Nifedipine) and ${ }^{* *} \mathrm{p}<0.01$ vs cytokines (+ Nifedipine). Data expressed as mean \pm SEM. $\mathrm{n}=3$ for siRNA and $\mathrm{n}=5$ for Nifedipine studies (non-asthmatic males).

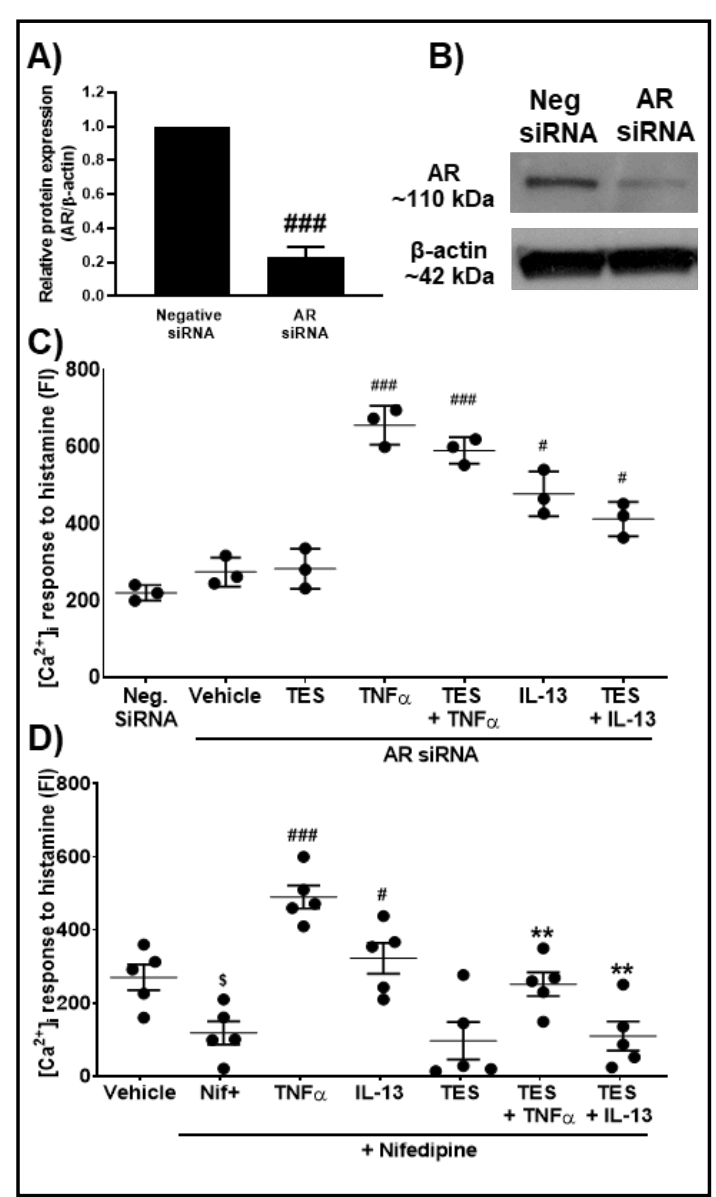




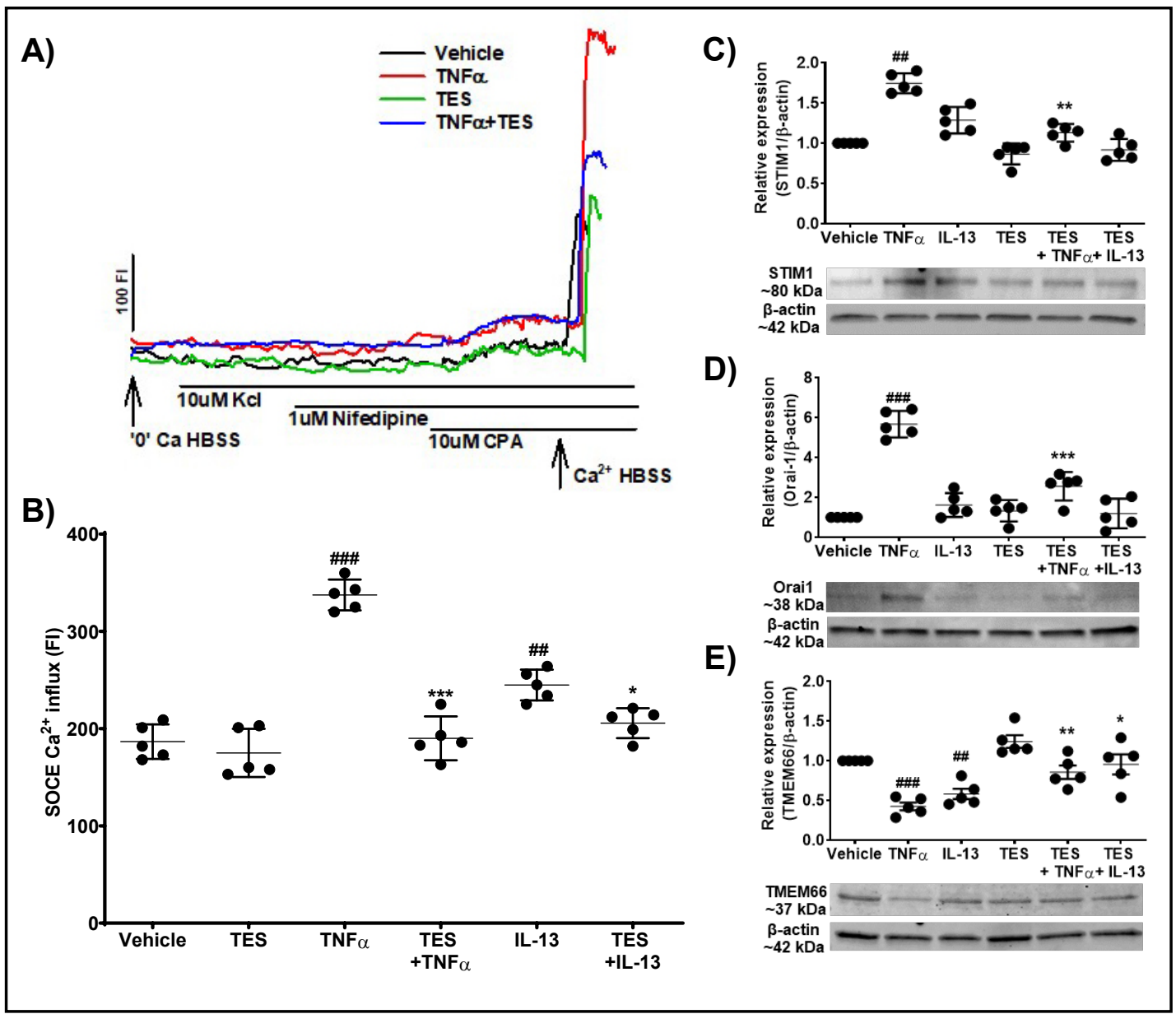

Fig. 7. Effect of TES on regulating store operated calcium entry (SOCE) during exposure to pro-inflammatory cytokines (TNF $\alpha$ and IL-13) in human ASM cells. A) Representative traces of SOCE in cells exposed vehicle, TNF $\alpha$, TES and TES + TNF $\alpha$. B) Effect of TES on regulating SOCE during exposure to TNF $\alpha$ and IL-13 in human ASM cells. C) Effect of TES on the expression of STIM1 in the presence/absence of TNF $\alpha$ and IL-13. D) Effect of TES on the expression of Orai1 in the presence/absence of TNF $\alpha$ and IL-13. E) Effect of TES on

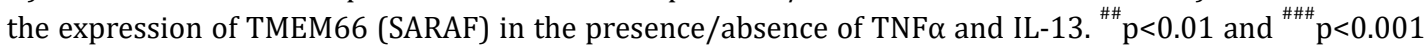
vs. vehicle and ${ }^{*} \mathrm{p}<0.05,{ }^{* *} \mathrm{p}<0.01$ and ${ }^{* * *} \mathrm{p}<0.001$ vs TNF $\alpha$. Data expressed as mean \pm SEM. $\mathrm{n}=5$ patients (non-asthmatic males).

Both non-asthmatic and asthmatic ASM cells demonstrated robust SOCC (as also previously shown [35, 38-40]. Non-asthmatic cells from males exposed to TNF $\alpha$ showed significant increase $(\mathrm{p}<0.001)$ in SOCE compared to vehicle. While TES did not influence the amplitude of SOCE per se, TES significantly reduced SOCE in the presence of TNF $\alpha(p<0.001)$. IL-13 exposed cells showed a significant increase $(p<0.01)$ in SOCE compared to vehicle, which was significantly decreased $(\mathrm{p}<0.05)$ by TES (Fig. 7A and 7B). In addition, Western analysis showed significant increase in the expression of STIM1 ( $<<0.01$, Fig. $7 C$ ) and Orai1 $(p<0.001$, Fig. 7D) with exposure to TNF $\alpha$, which was significantly downregulated $(p<0.01$ for STIM1 and $\mathrm{p}<0.001$ for Orai1) by pre-treatment with TES. Furthermore, TNF $\alpha$ exposed human ASM cells showed significant decrease in the expression of TMEM66 $(\mathrm{p}<0.001$, Fig. $7 \mathrm{E})$, but TMEM66 was significantly increased $(\mathrm{p}<0.01)$ by pre-treatment with TES. IL-13 exposed cells did not show any significant changes in the expression of STIM1 and Orai1, but TMEM66 was significantly decreased $(\mathrm{p}<0.01)$ compared to vehicle: an effect blunted by TES $(\mathrm{p}<0.05)$. 


\section{Cellular Physiology Cell Physiol Biochem 2019;53:215-228 \\ \begin{tabular}{ll|l} 
and Biochemistry $10.33594 / 000000131$ & (c) 2019 The Author(s). Published by \\
Cell Physiol Biochem Press GmbH\&Co. KG
\end{tabular} \\ Kalidhindi et al.: Androgen Receptor in Airway Smooth Muscle}

\section{Discussion}

Asthma is increasing in prevalence, with substantial morbidity $[5,12,41,42]$. The etiology of asthma involves inflammation, remodeling and AHR with an important role for ASM [5, 9, 10, 12, 43-47]. Evidence from clinical studies suggest sex differences in the prevalence of asthma, and a potential role of sex steroids in the pathophysiology [4-6, 4852]. However, the protective vs. detrimental roles of sex steroids is less clear. Here, much of the focus has been on female sex steroids, including effects on ASM [5, 14-16, 18, 37, 5356], but the relative importance of male sex steroids has been less examined. In this study, we explored AR-mediated effects in the context of $\left[\mathrm{Ca}^{2+}\right]_{\mathrm{i}}$ regulation and its modulation by disease (asthma) and inflammatory cytokines, finding that TES reduces ASM $\left[\mathrm{Ca}^{2+}\right]_{\mathrm{i}}$ responses by inhibiting $\mathrm{Ca}^{2+}$ influx and expression of relevant proteins, and is effective even in the presence of inflammation.

In animal models, significant differences between males and females with regards to fetal lung development have been reported such as delayed maturation and less surfactant in males: differences that extend to adulthood in the context of disease where for example, greater allergic airway responses are observed in female mice as well as in castrated male mice, as well as greater AHR with cholinergic stimulation in male mice $[15,17,20,21,30$, $31,50]$. While these data are consistent with epidemiological data suggesting women are more susceptible to asthma compared to men, they also are in contrast to a number of studies showing "protective" effects of female sex steroids in the context of ASM $\left[\mathrm{Ca}^{2+}\right]_{\mathrm{i}}$ and contractility [16], remodeling [14, 57] and AHR [15]. Regardless, these and other data also suggest a protective role of the male sex hormone testosterone [50-52, 58]. Our data are consistent in this regard, and explore potential mechanisms of TES action.

Testosterone elicits its action through AR both genomically and non-genomically [28, $59,60]$. Several studies have reported non-genomic efefcts of TES on ASM but have relied on animal models or cells derived from non-human species [17, 19, 26, 32]. There is no information on the expression profile of AR in human ASM, especially during inflammation, or on effects of long-term activation of AR on ASM in the context of $\left[\mathrm{Ca}^{2+}\right]_{\mathrm{i}}$ homeostasis. Here, it is important to recognize that AR expression is not limited to airways of females, raising the question of whether or not AR functionality exists in both sexes and if they are quantitatively or qualitatively different. In this study, we explored sex-specific differential expression of AR in both non-asthmatic and asthmatic primary human ASM cells in the presence/absence of pro-inflammatory cytokines (TNF $\alpha$ and IL-13). Our studies indicate a baseline difference in the expression of AR in ASM of females (low) vs. males (high) which in many ways is to be expected, given the usual low level of androgen ligand in females and the known regulation of AR expression by receptor stimulation $[28,61]$, thus resulting in reduced receptor levels in the absence of stimulation. An interesting finding however was a significant increase in AR expression in asthmatic ASM of both sexes, which likely occurs in females independent of changes in androgen levels. The effects of inflammation per se is suggested by the findings of increased AR expression in both non-asthmatic and asthmatic ASM with cytokine exposure. With inflammation known to enhance contractility [38,39], increased AR expression permits continued bronchodilatory effects of TES. What is less clear is the functional significance of such increased AR expression in female airways where TES or other androgens are likely to be still at very low levels.

Our studies show that TES, via AR, reduce $\left[\mathrm{Ca}^{2+}\right]_{\mathrm{i}}$ responses to agonist in both male and female ASM, highligthing functionality of the AR in both sexes. Interestingly, consistent with upregulated AR in both males and females, TES continued to reduce $\left[\mathrm{Ca}^{2+}\right]_{\mathrm{i}}$ even in asthmatic ASM or with TNF $\alpha$ or IL-13 exposure, suggesting maintained functionality that would be of physiological significance at least in males. However, it is also interesting to note that the decrease in $\left[\mathrm{Ca}^{2+}\right]_{\mathrm{i}}$ by TES or DHT was more pronounced in female asthmatics (again consistent with the greater change in AR in this sex). This surprising finding suggests a potentially novel approach to inducing bronchodilation in females by targeting the AR, 


\section{Cellular Physiology Cell Physiol Biochem 2019;53:215-228

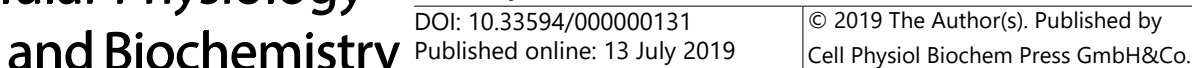 \\ Kalidhindi et al.: Androgen Receptor in Airway Smooth Muscle}

especially if done by local administration to the airways to minimize systemic androgenic effects in women.

The likely genomic effects of TES following extended exposure appear to target $\left[\mathrm{Ca}^{2+}\right]_{\mathrm{I}}$ regulatory mechanisms that are known to be increased in the context of asthma or cytokine exposure: LTCC, STIM1 and Orai1 [38-40, 62]. These $\mathrm{Ca}^{2+}$ influx mechanisms are also involved in mediating TES effects on $\left[\mathrm{Ca}^{2+}\right]_{i}$ as suggested by the effects of inhibitors such as nifedipine. Earlier studies suggest, TES inhibits LTCC non-genomically [62]. However, limited data in other cell types suggest TES actually increases LTCC [63]. Thus TES effects on this pathway may be cell-type dependent. Furthermore, $\left[\mathrm{Ca}^{2+}\right]_{\mathrm{i}}$ studies performed in zero extracellular calcium especially in the presence of TNF $\alpha$ or IL-13 show significant effects of TES/DHT suggesting a role for sarcoplasmic reticulum $\mathrm{Ca}^{2+}$ release pathways such as the IP3 or RyR receptors that are known to be important in ASM Ca ${ }^{2+}$ regulation [11, 38, 40, 64, 65]. Here, limited evidence does show that TES directly binds to IP3R and modifies its function in ASM [32].

Exploration of SOCE showed increased influx via this pathway following TNF $\alpha$ and to a lesser extent IL-13 exposure. TNF $\alpha$ and IL-13 have been shown to increase SOCE activity by increasing expression of the regulatory STIM1 protein and the Orai1 channel as well as downregulating TMEM66 in human ASM cells [18, 40, 64]. TNF $\alpha$ induced enhancement of SOCE was blunted by TES as was expression of STIM1 and Orai1 with concordant increase in TMEM66 that is involved in downregulating SOCE.

\section{Conclusion}

In conclusion, AR is expressed and is functional in ASM of both males and females, with a surprising greater increase in female ASM in asthmatics or with inflammaotry cytokine exposure. AR remains functional in disease, and its activation leads to decreased $\left[\mathrm{Ca}^{2+}\right]_{\mathrm{i}}$ via both inhibited $\mathrm{Ca}^{2+}$ influx and reduced intracellular $\mathrm{Ca}^{2+}$ release. Thus AR activation may be a viable and interesting apporach to inducing bronchodilation in both sexes.

\section{Acknowledgements}

This study was supported by NIH Grants R01-HL123494 and R01-HL123494-02S1 (Venkatachalem), R01-HL088029 (Prakash), R01-HL142061 (Pabelick, Prakash) ND EPSCoR with NSF\#1355466 and NDSU RCA.

Authors would like to thank Dr. Jagadish Loganathan and Dr. Nilesh Sudhakar Ambhore, Department of Pharmaceutical Sciences, NDSU for providing technical support in completion of this study.

\section{Disclosure Statement}

The authors of this manuscript declare no competing interests.

\section{References}

1 Postma DS, Timens W: Remodeling in asthma and chronic obstructive pulmonary disease. Proc Am Thorac Soc 2006;3:434-439.

2 Wenzel SE, Robinson CB, Leonard JM, Panettieri RA Jr.: Nebulized dehydroepiandrosterone-3-sulfate improves asthma control in the moderate-to-severe asthma results of a 6-week, randomized, double-blind, placebo-controlled study. Allergy Asthma Proc 2010;31:461-471. 


\section{Cellular Physiology Cell Physiol Biochem 2019;53:215-228 \begin{tabular}{l|l|l|l} 
DOI: 10.33594/000000131 & ( 2019 The Author(s). Published by \\
\hline
\end{tabular} and Biochemistry Published online: 13 July 2019 Cell Physiol Biochem Press GmbH\&Co. KG \\ Kalidhindi et al.: Androgen Receptor in Airway Smooth Muscle}

3 Centers for Disease Control and Prevention. National Center for Health Statistics. National Health Interview Survey, 2016. Analysis by the American Lung Association Epidemiology and Statistics Unit using SPSS software.

4 Becklake MR, Kauffmann F: Gender differences in airway behaviour over the human life span. Thorax 1999;54:1119-1138.

5 Sathish V, Martin YN, Prakash YS: Sex steroid signaling: implications for lung diseases. Pharmacol Ther 2015;150:94-108.

6 Ciprandi G, Gallo F: The impact of gender on asthma in the daily clinical practice. Postgrad Med 2018:1-3.

7 Fuentes N, Silveyra P: Endocrine regulation of lung disease and inflammation. Exp Biol Med (Maywood) 2018;243:1313-1322.

8 Townsend EA, Miller VM, Prakash YS: Sex differences and sex steroids in lung health and disease. Endocr Rev 2012;33:1-47.

9 Rydell-Tormanen K, Risse PA, Kanabar V, Bagchi R, Czubryt MP, Johnson JR: Smooth muscle in tissue remodeling and hyper-reactivity: airways and arteries. Pulm Pharmacol Ther 2013;26:13-23.

10 Prakash YS: Airway smooth muscle in airway reactivity and remodeling: what have we learned? Am J Physiol Lung Cell Mol Physiol 2013;305:L912-933.

11 Prakash YS, Thompson MA, Vaa B, Matabdin I, Peterson TE, He T, Pabelick CM: Caveolins and intracellular calcium regulation in human airway smooth muscle. Am J Physiol Lung Cell Mol Physiol 2007;293:L11181126.

12 Prakash YS: Emerging concepts in smooth muscle contributions to airway structure and function: implications for health and disease. Am J Physiol Lung Cell Mol Physiol 2016;311:L1113-L1140.

13 Wang SY, Freeman MR, Sathish V, Thompson MA, Pabelick CM, Prakash YS: Sex Steroids Influence Brain-Derived Neurotropic Factor Secretion From Human Airway Smooth Muscle Cells. J Cell Physiol 2016;231:1586-1592.

14 Ambhore NS, Katragadda R, Raju Kalidhindi RS, Thompson MA, Pabelick CM, Prakash YS, Sathish V: Estrogen receptor beta signaling inhibits PDGF induced human airway smooth muscle proliferation. Mol Cell Endocrinol 2018;476:37-47.

15 Ambhore NS, Raju KR, Loganathan J, Sathish V: Role of differential estrogen receptor activation on airway hyperreactivity and remodeling in a murine model of asthma. Am J Res Cell Mol Biol 2019; DOI:10.1165/ rcmb.2018-03210C.

16 Townsend EA, Sathish V, Thompson MA, Pabelick CM, Prakash YS: Estrogen effects on human airway smooth muscle involve cAMP and protein kinase A. Am J Physiol Lung Cell Mol Physiol 2012;303:L923-928.

17 Perusquia M, Flores-Soto E, Sommer B, Campuzano-Gonzalez E, Martinez-Villa I, Martinez-Banderas AI, Montano LM: Testosterone-induced relaxation involves L-type and store-operated $\mathrm{Ca}^{2+}$ channels blockade, and PGE 2 in guinea pig airway smooth muscle. Pflugers Arch 2015;467:767-777.

18 Sathish V, Freeman MR, Long E, Thompson MA, Pabelick CM, Prakash YS: Cigarette Smoke and Estrogen Signaling in Human Airway Smooth Muscle. Cell Physiol Biochem 2015;36:1101-1115.

19 Montano LM, Espinoza J, Flores-Soto E, Chavez J, Perusquia M: Androgens are bronchoactive drugs that act by relaxing airway smooth muscle and preventing bronchospasm. J Endocrinol 2014;222:1-13.

20 Espinoza J, Montano LM, Perusquia M: Nongenomic bronchodilating action elicited by dehydroepiandrosterone (DHEA) in a guinea pig asthma model. J Steroid Biochem Mol Biol 2013;138:174182.

21 Bordallo J, de Boto MJ, Meana C, Velasco L, Bordallo C, Suarez L, Cantabrana B, Sanchez M: Modulatory role of endogenous androgens on airway smooth muscle tone in isolated guinea-pig and bovine trachea; involvement of beta2-adrenoceptors, the polyamine system and external calcium. Eur J Pharmacol 2008;601:154-162.

22 Rubio-Gayosso I, Garcia-Ramirez 0, Gutierrez-Serdan R, Guevara-Balcazar G, Munoz-Garcia 0, MoratoCartajena T, Zamora-Garza M, Ceballos-Reyes G: Testosterone inhibits bradykinin-induced intracellular calcium kinetics in rat aortic endothelial cells in culture. Steroids 2002;67:393-397.

23 Sochorova R, Mosnarova A, Huzulakova I: The possible influence of testosterone on calcium ion transport (investigated) in guinea pig uterus. Acta Physiol Hung 1991;77:19-24.

24 Saldanha PA, Cairrao E, Maia CJ, Verde I: Long- and short-term effects of androgens in human umbilical artery smooth muscle. Clin Exp Pharmacol Physiol 2013;40:181-189. 


\section{Cellular Physiology Cell Physiol Biochem 2019;53:215-228

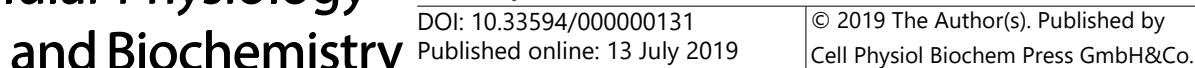 \\ Kalidhindi et al.: Androgen Receptor in Airway Smooth Muscle}

25 Jones RD, English KM, Pugh PJ, Morice AH, Jones TH, Channer KS: Pulmonary vasodilatory action of testosterone: evidence of a calcium antagonistic action. J Cardiovasc Pharmacol 2002;39:814-823.

26 Kouloumenta V, Hatziefthimiou A, Paraskeva E, Gourgoulianis K, Molyvdas PA: Non-genomic effect of testosterone on airway smooth muscle. Br J Pharmacol 2006;149:1083-1091.

27 Flores-Soto E, Reyes-Garcia J, Carbajal-Garcia A, Campuzano-Gonzalez E, Perusquia M, Sommer B, Montano LM: Sex steroids effects on guinea pig airway smooth muscle tone and intracellular $\mathrm{Ca}^{2+}$ basal levels. Mol Cell Endocrinol 2017;439:444-456.

28 Mikkonen L, Pihlajamaa P, Sahu B, Zhang FP, Janne OA: Androgen receptor and androgen-dependent gene expression in lung. Mol Cell Endocrinol 2010;317:14-24.

29 McEwan IJ, Brinkmann AO: Androgen Physiology: Receptor and Metabolic Disorders; in De Groot LJ, Chrousos G, Dungan K, Feingold KR, Grossman A, Hershman JM, Koch C, Korbonits M, McLachlan R, New M, Purnell J, Rebar R, Singer F, Vinik A (eds): Endotext. South Dartmouth (MA), 2000

30 Cephus JY, Stier MT, Fuseini H, Yung JA, Toki S, Bloodworth MH, Zhou W, Goleniewska K, Zhang J, Garon SL, Hamilton RG, Poloshukin VV, Boyd KL, Peebles RS, Jr., Newcomb DC: Testosterone Attenuates Group 2 Innate Lymphoid Cell-Mediated Airway Inflammation. Cell Rep 2017;21:2487-2499.

31 Fuseini H, Yung JA, Cephus JY, Zhang J, Goleniewska K, Polosukhin VV, Peebles RS, Jr., Newcomb DC: Testosterone Decreases House Dust Mite-Induced Type 2 and IL-17A-Mediated Airway Inflammation. J Immunol 2018;201:1843-1854.

32 Montano LM, Flores-Soto E, Reyes-Garcia J, Diaz-Hernandez V, Carbajal-Garcia A, Campuzano-Gonzalez E, Ramirez-Salinas GL, Velasco-Velazquez MA, Sommer B: Testosterone induces hyporesponsiveness by interfering with IP3 receptors in guinea pig airway smooth muscle. Mol Cell Endocrinol 2018;473:17-30.

33 Foradori CD, Werner SB, Sandau US, Clapp TR, Handa RJ: Activation of the androgen receptor alters the intracellular calcium response to glutamate in primary hippocampal neurons and modulates sarco/ endoplasmic reticulum calcium ATPase 2 transcription. Neuroscience 2007;149:155-164.

34 Abcejo AJ, Sathish V, Smelter DF, Aravamudan B, Thompson MA, Hartman WR, Pabelick CM, Prakash YS: Brain-derived neurotrophic factor enhances calcium regulatory mechanisms in human airway smooth muscle. PLoS One 2012;7:e44343.

35 Vohra PK, Thompson MA, Sathish V, Kiel A, Jerde C, Pabelick CM, Singh BB, Prakash YS: TRPC3 regulates release of brain-derived neurotrophic factor from human airway smooth muscle. Biochim Biophys Acta 2013;1833:2953-2960.

36 Loganathan J, Pandey R, Ambhore NS, Borowicz P, Sathish V: Laser-capture microdissection of murine lung for differential cellular RNA analysis. Cell Tissue Res 2019;376:425-432.

37 Aravamudan B, Goorhouse KJ, Unnikrishnan G, Thompson MA, Pabelick CM, Hawse JR, Prakash YS, Sathish V: Differential Expression of Estrogen Receptor Variants in Response to Inflammation Signals in Human Airway Smooth Muscle. J Cell Physiol 2017;232:1754-1760.

38 Sathish V, Thompson MA, Bailey JP, Pabelick CM, Prakash YS, Sieck GC: Effect of proinflammatory cytokines on regulation of sarcoplasmic reticulum $\mathrm{Ca}^{2+}$ reuptake in human airway smooth muscle. Am J Physiol Lung Cell Mol Physiol 2009;297:L26-34.

39 Sathish V, Abcejo AJ, VanOosten SK, Thompson MA, Prakash YS, Pabelick CM: Caveolin-1 in cytokineinduced enhancement of intracellular $\mathrm{Ca}^{2+}$ in human airway smooth muscle. Am J Physiol Lung Cell Mol Physiol 2011;301:L607-614.

40 Sathish V, Abcejo AJ, Thompson MA, Sieck GC, Prakash YS, Pabelick CM: Caveolin-1 regulation of storeoperated $\mathrm{Ca}^{2+}$ influx in human airway smooth muscle. Eur Respir J 2012;40:470-478.

41 Raju KR, Ambhore NS, Mulukutla S, Gupta S, Murthy V, Kumar MN, Madhunapantula SR, Kuppuswamy G, Elango K: Salicylic acid derivatives as potential anti asthmatic agents using disease responsive drug delivery system for prophylactic therapy of allergic asthma. Med Hypotheses 2016;87:75-79.

42 Raju KR, Kumar MN, Gupta S, Naga ST, Shankar JK, Murthy V, Madhunapanthula SR, Mulukutla S, Ambhore NS, Tummala S, Vishnuvarthan VJ, Azam A, Elango K: 5-Aminosalicylic acid attenuates allergen-induced airway inflammation and oxidative stress in asthma. Pulm Pharmacol Ther 2014;29:209-216.

43 Lazaar AL, Panettieri RA, Jr:: Airway smooth muscle: a modulator of airway remodeling in asthma. J Allergy Clin Immunol 2005;116:488-495; quiz 496.

44 Dekkers BG, Maarsingh H, Meurs H, Gosens R: Airway structural components drive airway smooth muscle remodeling in asthma. Proc Am Thorac Soc 2009;6:683-692. 


\section{Cellular Physiology Cell Physiol Biochem 2019;53:215-228 \begin{tabular}{c|c|c|c|}
\hline DOI: 10.33594/000000131 & 2019 The Author(s). Published by \\
\hline and Biochemistry
\end{tabular} and Biochemistry Published online: 13 July 2019 Cell Physiol Biochem Press GmbH\&Co. KG \\ Kalidhindi et al:: Androgen Receptor in Airway Smooth Muscle}

45 Cheng Z, Wang X, Dai LL, Jia LQ, Jing XG, Liu Y, Wang H, Li PF, An L, Liu M: Thymic stromal lymphopoietin signaling pathway inhibition attenuates airway inflammation and remodeling in rats with asthma. Cellular Physiology and Biochemistry 2018;47:1482-1496.

46 Song L, Tang H, Liu D, Song J, Wu Y, Qu S, Li Y: The chronic and short-term effects of gefinitib on airway remodeling and inflammation in a mouse model of asthma. Cellular Physiology and Biochemistry 2016;38:194-206.

47 Wang J, Li HY, Wang HS, Su ZB: MicroRNA-485 Modulates the TGF- $\beta$ /Smads Signaling Pathway in Chronic Asthmatic Mice by Targeting Smurf2. Cellular Physiology and Biochemistry 2018;51:692-710.

48 Bonds RS, Midoro-Horiuti T: Estrogen effects in allergy and asthma. Curr Opin Allergy Clin Immunol 2013;13:92-99.

49 Bjornson CL, Mitchell I: Gender differences in asthma in childhood and adolescence. J Gend Specif Med 2000;3:57-61.

50 Carey MA, Card JW, Voltz JW, Arbes SJ, Jr., Germolec DR, Korach KS, Zeldin DC: It's all about sex: gender, lung development and lung disease. Trends Endocrinol Metab 2007;18:308-313.

51 Caracta CF: Gender differences in pulmonary disease. Mt Sinai J Med 2003;70:215-224.

52 Melgert BN, Ray A, Hylkema MN, Timens W, Postma DS: Are there reasons why adult asthma is more common in females? Curr Allergy Asthma Rep 2007;7:143-150.

53 Dimitropoulou C, Drakopanagiotakis F, Catravas JD: Estrogen as a new therapeutic target for asthma and chronic obstructive pulmonary disease. Drug News Perspect 2007;20:241-252.

54 Stamatiou R, Paraskeva E, Papagianni M, Molyvdas PA, Hatziefthimiou A: The mitogenic effect of testosterone and 17beta-estradiol on airway smooth muscle cells. Steroids 2011;76:400-408.

55 Carey MA, Card JW, Voltz JW, Germolec DR, Korach KS, Zeldin DC: The impact of sex and sex hormones on lung physiology and disease: lessons from animal studies. Am J Physiol Lung Cell Mol Physiol 2007;293:L272-278.

56 Verma MK, Miki Y, Sasano H: Sex steroid receptors in human lung diseases. J Steroid Biochem Mol Biol 2011;127:216-222.

57 Ambhore NS, Raju KR, Pabelick CM, Prakash YS, Sathish V: Receptor Specific Estrogen Signaling Regulates Extracellular Matrix Deposition in Human Airway Smooth Muscle Remodeling. Am J Respir Crit Care Med 2019;199:A2189.

58 Tam A, Morrish D, Wadsworth S, Dorscheid D, Man SF, Sin DD: The role of female hormones on lung function in chronic lung diseases. BMC Womens Health 2011;11:24.

59 Wilson CM, McPhaul MJ: A and B forms of the androgen receptor are expressed in a variety of human tissues. Mol Cell Endocrinol 1996;120:51-57.

60 Mooradian AD, Morley JE, Korenman SG: Biological actions of androgens. Endocr Rev 1987;8:1-28.

61 Gao T, McPhaul MJ: Functional activities of the A and B forms of the human androgen receptor in response to androgen receptor agonists and antagonists. Mol Endocrinol 1998;12:654-663.

62 Scragg JL, Jones RD, Channer KS, Jones TH, Peers C: Testosterone is a potent inhibitor of L-type Ca(2+) channels. Biochem Biophys Res Commun 2004;318:503-506.

63 Er F, Michels G, Brandt MC, Khan I, Haase H, Eicks M, Lindner M, Hoppe UC: Impact of testosterone on cardiac L-type calcium channels and $\mathrm{Ca}^{2+}$ sparks: acute actions antagonize chronic effects. Cell Calcium 2007;41:467-477.

64 Prakash YS, Sathish V, Thompson MA, Pabelick CM, Sieck GC: Asthma and sarcoplasmic reticulum $\mathrm{Ca}^{2+}$ reuptake in airway smooth muscle. Am J Physiol Lung Cell Mol Physiol 2009;297:L794.

65 Park KM, Yule DI, Bowers WJ: Tumor necrosis factor-alpha potentiates intraneuronal $\mathrm{Ca}^{2+}$ signaling via regulation of the inositol 1,4,5-trisphosphate receptor. J Biol Chem 2008;283:33069-33079. 